\title{
Physiology, yield and quality of soybean as affected by drought stress
}

\begin{abstract}
Oqba Basal*, András Szabó
Department of Crop Production and Applied Ecology, Faculty of Agricultural and Food Sciences and Environmental Management, University of Debrecen, Debrecen, Hungary

Abstract

Drought stress is one of the most hazardous abiotic stresses increasingly affecting drought-sensitive crops like soybean. An experiment was conducted in Debrecen, Hungary in 2018 to investigate the influence of drought stress on physiology, yield and seed quality of three soybean cultivars different in maturity timing. Drought-stressed treatments of the three cultivars showed less normalized difference vegetation index (NDVI) and leaf area index (LAI) compared to fully-irrigated counterparts, whereas relative chlorophyll content (SPAD) did not measurably differ. Drought reduced the yield of the three cultivars, however, yield of middle maturity group cultivar was better than that of early maturity group cultivars, and the same conclusion was obtained from non-stressed treatments. Protein concentration changes were negligible.
\end{abstract}

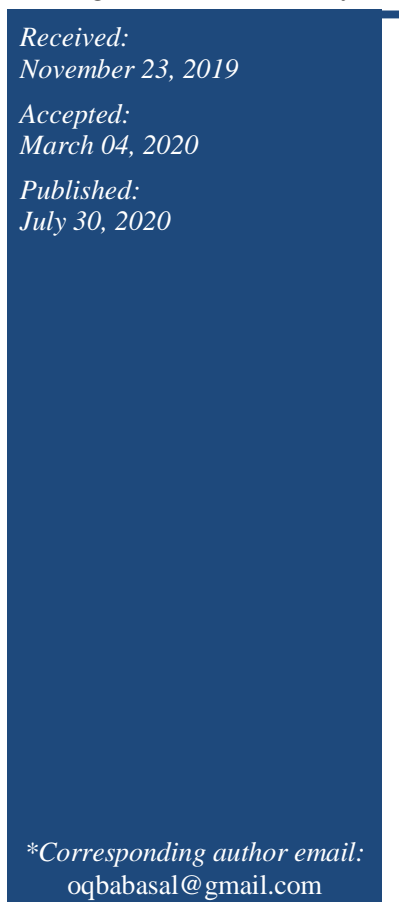

Keywords: Leaf area index, Normalized difference vegetation index, Protein concentration, Seed yield, Soybean

\section{How to cite this:}

Basal O and Szabó A, 2020. Physiology, yield and quality of soybean as affected by drought stress. Asian J. Agric. Biol. 8(3): 247-252. DOI: https://doi.org/10.35495/ajab.2019.11.505

This is an Open Access article distributed under the terms of the Creative Commons Attribution 3.0 License. (https://creativecommons.org/licenses/by/3.0), which permits unrestricted use, distribution, and reproduction in any medium, provided the original work is properly cited.

\section{Introduction}

Soybean (Glycine max (L.) Merrill) is among the 10 most grown crops worldwide (He et al., 2017), providing a cheap source of protein (Mutava et al., 2015); it also has the highest harvested area as an oilseed crop worldwide (Cerezini et al., 2016). Soybean is mostly grown as a rainfed crop (Manavalan et al., 2009). Climatic changes have induced abnormalities in precipitation rates and timings ( $\mathrm{Li}$ et al., 2013), imposing drought stress periods and raising questions about nourishment for the still-increasing world population (Vurukonda et al., 2016). Drought is among the most destructive abiotic stresses, and soybean's sensitivity to drought is relatively high, especially at particular phases of its life cycle (Liu et al., 2004); losses of soybean yield resulting from drought stress can reach $40 \%$ annually (Manavalan et al., 2009). Plants respond to drought with complex mechanisms on different levels; genetics, morphology and physiology (Rahdari and Hoseini, 2012); for example, alterations in light absorption can result from drought periods by changing the area index of the leaves (Dong et al., 2015). Hao et al. (2013) reported that chlorophyll content was reduced when soybean plants were subjected to drought. Generally, soybean yield is decreased by drought (Bajaj et al., 2008; Gercek et al., 2009), and different genotypes shows different decrease rates (He et al., 2017). Soybean seed quality, in addition to the yield, is also altered by drought (Vurukonda et al., 2016).

As soybean is newly engaged in the agricultural crop 
rotations in the study area, very little is known about the response of different cultivars of soybean to drought stress conditions. Moreover, apart from our previously published papers we couldn't find any papers demonstrating the influence of drought application on physiology and/or production and/or quality of soybean plants in the studied area. This experiment aimed to demonstrate the different effects of drought stress on the physiology, yield and quality of three soybean cultivars belonging to different maturity groups.

\section{Material and Methods}

Three soybean cultivars from different maturity group; Commandor (very early maturity group), Advisor (early maturity group) and Steara (middle maturity group) were sown in the experimental station of Debrecen University (Látókép) (N. latitude 47³ 33', E. longitude $21^{\circ} 27^{\prime}$ ) in 2018 . The three cultivars were sown on April $26^{\text {th }}$ and both Commandor and Advisor were harvested on September $1^{\text {st }}$, whereas Steara was harvested on September $15^{\text {th }}$. The plot dimensions were $3 * 9.25=27.75 \mathrm{~m}^{2}$. The number of rows per plot was 6 , and the number of plots was 24 ( 3 cultivars*4 replications $* 2$ irrigation treatments). Two irrigation treatments were applied; drought-stressed (DS) (where plants relied only on precipitation as the source of water supply) and fully-irrigated (FI) (where three irrigation occasions, in addition to the precipitation amounts, were applied with the following amounts and dates (based on water demands as recommended by farm management); $25 \mathrm{~mm}$ on June $25^{\text {th }}, 25 \mathrm{~mm}$ on July $4^{\text {th }}$ and $25 \mathrm{~mm}$ on July $16^{\text {th }}$ ) (Figure- 1 ).

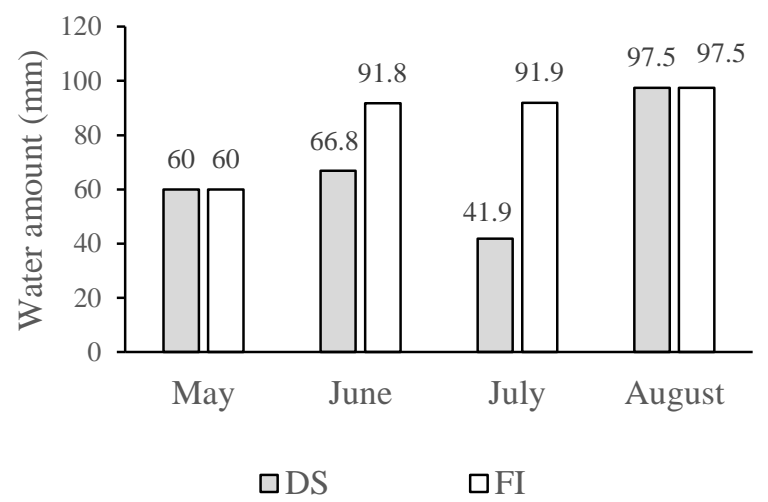

Figure-1. Water amounts applied in droughtstressed (DS) and fully-irrigated (FI) treatments to the three studied soybean cultivars during the vegetative period in 2018.
Leaf area index (LAI) values were recorded using SS1 - SunScan canopy analysis system (Delta- T Devices, UK). Relative chlorophyll content (SPAD) was measured using SPAD-502Plus (Konica Minolta, Japan). Normalized difference vegetation index (NDVI) values were recorded using Trimble Greenseeker Handheld (AS Communications Ltd, UK). For every trait, 10 plants were randomly chosen from the middle rows of each plot, and the average was calculated. The three traits were measured at full pod (R4) stage (Fehr and Caviness, 1977). The yield was determined by harvesting the middle 4 rows of each plot, and the protein concentration in the harvested seeds was determined using NIR analyser Granolyser (Pfeuffer, Germany).

Analysis of variance (ANOVA) was run in order to compare the means of each trait and to indicate the effect size of each treatment, followed by Tukey posthoc test in order to report the means that are statistically significant. Pearson's correlation test was conducted to calculate correlation coefficient (IBM SPSS ver.25, USA software).

\section{Results and Discussion}

\section{Normalized difference vegetation index (NDVI)}

Drought reduced NDVI of all three cultivars, regardless of maturity group; the reduction was $2.2 \%$, $1.9 \%$ and $2.9 \%$ in Commandor, Advisor and Steara, respectively (Figure 2).

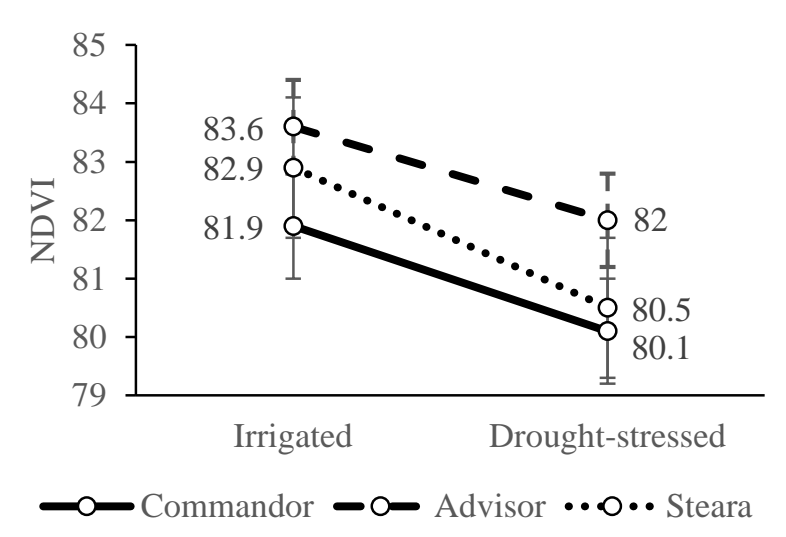

Figure-2. Normalized difference vegetation index (NDVI) under drought stressed (DS) and fullyirrigated (FI) treatments for three soybean cultivars in Debrecen 2018.

Although the reduction was insignificant, yet drought was still responsible for an average of $35.5 \%$ of the 
NDVI reduction (as calculated by Partial Eta Squared), and the correlation with irrigation was positive; i.e. irrigation increased this trait and drought, in turn, reduced it (Table 1). Previously it was reported that reducing irrigation by $25 \%$ as compared to the control (non-stressed) treatment insignificantly reduced NDVI of pepper plants by $2.4 \%$, whereas a $50 \%$ reduction in irrigation water amount resulted in a significant 9.5\% NDVI reduction (Camoglu et al., 2018). Moreover, some papers reported positive correlations between irrigation and NDVI (e.g. Suzuki et al., 2000; Wang et al., 2001).

Table-1. Correlation between irrigation and the studied traits.

\begin{tabular}{|l|l|l|l|l|l|}
\hline Cultivar & SPAD & NDVI & LAI & Yield & Protein Concentration \\
\hline Commandor & .089 & .585 & .527 & .576 & .282 \\
\hline Advisor & -.084 & .616 & .371 & $.711^{*}$ & .163 \\
\hline Steara & -.096 & .586 & .564 & .517 & -.214 \\
\hline
\end{tabular}

*. Correlation is significant at the 0.05 level (2-tailed).

\section{Relative chlorophyll content (SPAD)}

Commandor plants recorded less SPAD values under drought conditions, whereas both Advisor and Steara plants could slightly increase the relative chlorophyll content under drought stress conditions. However, all differences were insignificant (Figure-3) and drought effect was less than $0.1 \%$ for all three cultivars.

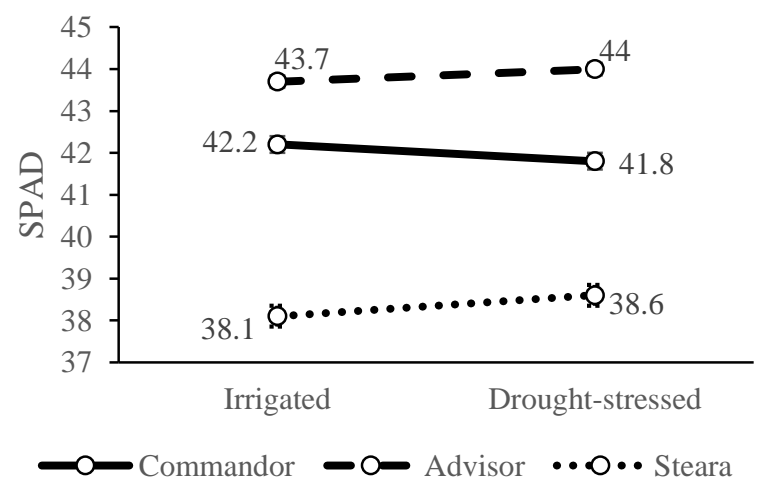

Figure-3. Relative chlorophyll content (SPAD) under drought stressed (DS) and fully-irrigated (FI) treatments for three soybean cultivars in Debrecen 2018.

The correlation coefficient was also small (Table-1). These results lead to a conclusion that SPAD is not a reliable trait to count on when studying physiological changes resulting from drought stress application in these cultivars. Cerezini et al. (2016) reported a non- significant decrease in the chlorophyll content when soybean plants suffered from drought conditions at full bloom (R2) stage, and Inamullah and Isoda (2005) reported reductions in chlorophyll content when soybean plants were subjected to continuous drought stress starting from beginning seed (R5) stage. Other studies concluded that chlorophyll decreases under drought stress conditions (e.g. Cui et al., 2004; Pagter et al., 2005).

\section{Leaf area index (LAI)}

Measurable reductions were recorded in LAI of all three cultivars as a result of drought stress application (Figure-4); the reduction ratios were 19.4\%, 20.6\% and $25.7 \%$ for Commandor, Advisor and Steara, respectively.

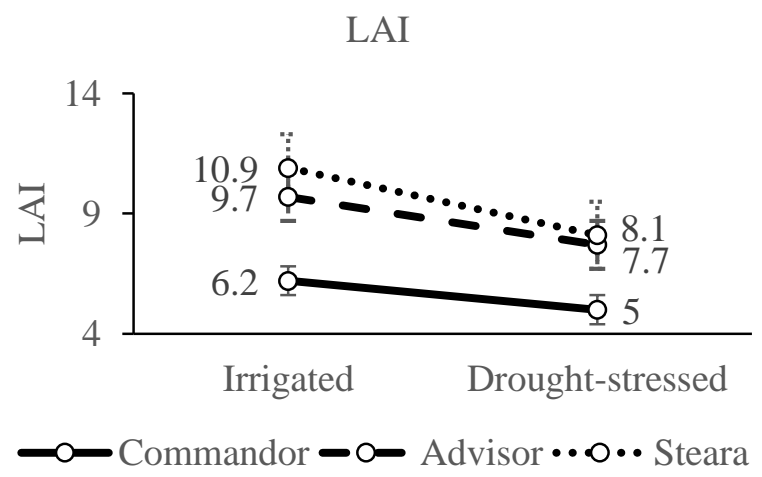

Figure-4. Leaf area index (LAI) under drought stressed (DS) and fully-irrigated (FI) treatments for three soybean cultivars in Debrecen 2018.

Drought effect on LAI trait was higher in Commandor (27.8\%) and Steara (31.8\%) than in Advisor (13.7\%), which was further demonstrated by the higher correlation coefficient (Table-1). The leaf area of plants per unit area of soil (LAI) is an expression of the canopy density of a crop population; it has an important effect on yield (Liu et al., 2005). Drought stress reduces leaf area, consequently, protein synthesis and yield decreases (Sinclair and Serraj, 1995; Purcell and King, 1996). Li et al. (2013) reported significant decreases in LAI (by $40,33.8$ and $36.4 \%$ ) when soybean plants were subjected to drought stress conditions at flowering, podding and seed-filling stages, respectively. Dong et al. (1979) reported LAI to be positively correlated with grain yield of eight soybean cultivars. Soybean genotype also plays a role in the LAI value and the corresponded yield; Liu et al. (2005) concluded that higher LAI in late maturity genotypes of soybean, compared to early 
and middle maturity group genotypes, increased solar energy interception, consequently, a greater $\mathrm{CO}_{2-}$ fixing ability which resulted in more assimilates accumulation. This latter conclusion supports our results on the yield as will be shown later.

\section{Yield (t ha-1)}

Similar to LAI trait, drought caused noticeable decreases in the yield of all three cultivars (Figure-5).

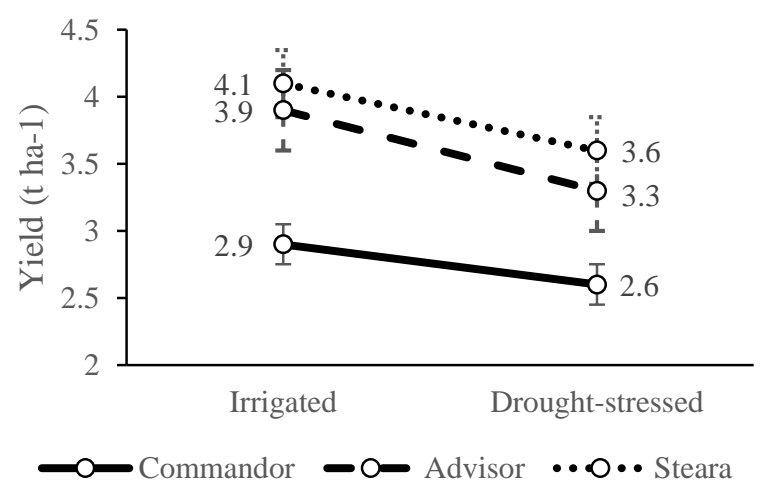

Figure-5. Yield (t ha-1) under drought stressed (DS) and fully-irrigated (FI) treatments for three soybean cultivars in Debrecen 2018.

Drought was responsible for $33.2 \%$ of yield reduction in Commandor plants, where the yield decreased by $10.3 \%$ compared to irrigated counterparts, whereas it was responsible for $26.8 \%$ of yield reduction in Steara plants (the reduction ratio was $12.2 \%$ ) and for $50.5 \%$ in Advisor plants where the yield decreased by $15.4 \%$. Yield correlation with irrigation was considerable in all three cultivars. Moreover, it was significant in Advisor plants (which is logical based on the high effect size of drought on the yield of this cultivar) (Table-1). Many papers concluded that soybean seed yield decreases under drought stress conditions (e.g. Dogan et al., 2007; Bajaj et al., 2008; Sincik et al., 2008; Sadeghipour and Abbasi, 2012). However, different cultivars reacted significantly different in terms of yield loss under drought conditions (Garcia et al., 2010; Maleki et al., 2013; He et al., 2017); that decrease was attributed to drought stress shortening seed-filling period and reducing seed yield (Smiciklas et al., 1992), whereas others suggested this reduction to be due to the reduction of seed number (Dornbos and Mullen, 1992), pod number (Atti et al., 2004) and seed weight (Samarah et al., 2006). In our experiment, yield increased as the days from planting to maturity (maturity group) increased, regardless of irrigation regime (figure 5), which is supported by the findings of Liu et al. (2005).

\section{Protein concentration}

The effect of drought on protein concentration was very small (less than 1\%) and insignificant in all three cultivars, and the correlation coefficient was, in turn, small (Table-1). The protein concentration decreased by $0.5 \%$ in both Commandor and Advisor plants whereas it increased by $1.7 \%$ in Steara plants (Figure6). Increased protein contents under drought stress were reported earlier (e.g. Rotundo and Westgate, 2009; Wang and Frei, 2011) and were explained by drought stress rapidly remobilizing nitrogen from leaves to seeds (Brevedan and Egli, 2003) which leads to increasing protein concentration, or by reducing seed number with increased seed size (Borras et al., 2004).

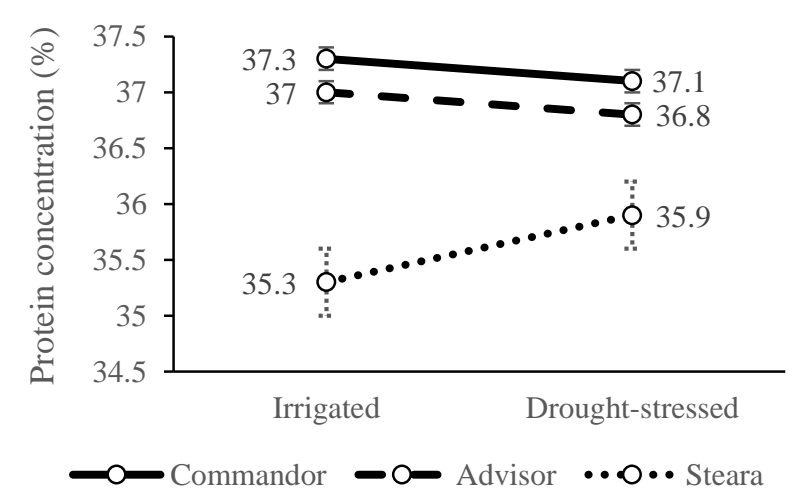

Figure-6. Protein concentration (\%) under drought stressed (DS) and fully-irrigated (FI) treatments for three soybean cultivars in Debrecen 2018.

However, other studies reported lower protein concentration under drought conditions (Boydak et al., 2002; Carrera et al., 2009). Medic et al. (2014) reported that the influence of drought stress on seed composition of soybean is controversial, and different conclusions are the result of different timings and different intensities of drought stress during different stages of soybean's life cycle (Carrera et al., 2009), in addition to the different responses to drought stress conditions by different cultivars (Bellaloui and Mengistu, 2008).

\section{Conclusion}

Drought manipulates soybean physiology and also the final yield and quality of the seeds; however, different 
cultivars respond differently to drought. SPAD values did not show much change as a result of drought, whereas both NDVI and LAI values were more affected and measurably reduced by drought, leading to a conclusion that these two traits are more reliable to count on when monitoring drought effects as compared to SPAD. The final yield was also noticeably reduced under drought stress conditions, however, early maturity cultivars were more affected than middle maturity cultivar, and this result was also recorded under non-stressed conditions. Protein concentration was not measurably affected by drought.

\section{Acknowledgment}

Authors highly acknowledge the financial support by the EFOP-3.6.3-VEKOP-16-2017-00008 project. They also acknowledge the European Union and the European Social Fund, the co-financer of the project.

\section{Disclaimer: None.}

Conflict of Interest: None.

Source of Funding: This study was supported by the EFOP-3.6.3-VEKOP-16-2017-00008 project. The project was also co-financed by the European Union and the European Social Fund.

\section{References}

Atti S, Bonnell R, Smith D and Prasher S, 2004. Response of an Indeterminate Soybean \{Glycine $\operatorname{Max}$ (L.) Merr \} to Chronic Water Deficit During Reproductive Development Under Greenhouse Conditions. Can. Water Resour. J. 29(4): 209-222.

Bajaj S, Chen P, Longer DE, Shi A, Hou A, Ishibashi T and Brye KR, 2008. Irrigation and planting date effects on seed yield and agronomic traits of earlymaturing Soybean. J. Crop Improv. 22 (1): 47-65.

Bellaloui N and Mengistu A, 2008. Seed composition is influenced by irrigation regimes and cultivar differences in soybean. Irrig. Sci. 26: 261-268.

Borras L, Slafer GA and Otegui M, 2004. Seed dry weight response to source-sink manipulations in wheat, maize and soybean: a quantitative reappraisal. Field Crop Res. 86: 131-146.

Boydak E, Alpaslan M, Hayta M, Gercek S and Simsek M, 2002. Seed composition of soybeans grown in the Harran region of Turkey as affected by row spacing and irrigation. J Agric Food Chem. 50: 4718-4720.
Brevedan RE and Egli DB, 2003. Short periods of water stress during seed filling, leaf senescence, and yield of soybean. Crop Sci. 43: 2083-2088.

Camoglu G, Demirel K and Genc L, 2018. Use of infrared thermography and hyperspectral data to detect effects of water stress on pepper. Quant Infr Therm J. 15(1): 81-94.

Carrera C, Martinez MJ, Dardanelli J and Balzarini M, 2009. Water deficit effect on the relationship between temperature during the seed fill period and soybean seed oil and protein concentrations. Crop Sci. 49: 990-998.

Cerezini P, Kuwano BH, dos Santos MB, Terassi F, Hungria $M$ and Nogueira MA, 2016. Strategies to promote early nodulation in soybean under drought. Field Crop Res. 196: 160-167.

Cui YY, Pandey DM, Hahn EJ and Paek KY, 2004. Effect of drought on physiological aspects of Crassulacean acid metabolism in Doritaenopsis. Plant Sci. 167: 1219-1226.

Dogan E, Kirnak H and Copur O, 2007. Deficit irrigations during soybean reproductive stages and CROPGRO-soybean simulations under semi-arid climatic conditions. Field Crop Res. 103 (2): 154159.

Dong J, Xiao X, Wagle P, Zhang G, Zhou Y, Jin C, Torn MS, Meyers TP, Suyker AE, Wang J, Yan H, Biradar Ch and Moore III B, 2015. Comparison of four EVI-based models for estimating gross primary production of maize and soybean croplands and tallgrass prairie under severe drought. Remote Sens Environ. 162: 154-168.

Dong Z, Bin YQ and Sun LQ, 1979. Comparison of cultivar productivity in soybean. J. Shenyang Agric. Coll. 1: 37-47 (in Chinese).

Dornbos DL and Mullen RE, 1992. Soybean seed protein and oil contents and fatty acid composition adjustments by drought and temperature. J. Am. Oil Chem. Soc. 69(3): 228-231.

Fehr WR and Caviness CE, 1977. Stages of soybean development. Special Report 87. http://lib.dr.iastate.edu/specialreports/87.

Garcia AG, Persson T, Guerra LC and Hoogenboom G, 2010. Response of soybean genotypes to different irrigation regimes in a humid region of the southeastern USA. Agric. Water Manage. 97: 981987.

Gercek S, Boydak E, Okant M and Dikilitas M, 2009. Water pillow irrigation compared to furrow irrigation for soybean production in a semi-arid area. Agric. Water Manage. 96(1): 87-92. 
Hao L, Wang Y, Zhang J, Xie Y, Zhang M, Duan L and $\mathrm{Li} \mathrm{Z}, 2013$. Coronatine enhances drought tolerance via improving antioxidative capacity to maintaining higher photosynthetic performance in soybean. Plant Sci. 210: 1-9.

He J, Du Y-L, Wang T, Turner NC, Yang R-P, Jin Y, Xi Y, Zhang C, Cui T, Fang X-W and Li F-M, 2017. Conserved water use improves the yield performance of soybean (Glycine max (L.) Merr.) under drought. Agric. Water Manage. 179: 236-245.

Inamullah I and Isoda A, 2005. Adaptive responses of soybean and cotton to water stress II. Changes in $\mathrm{CO} 2$ assimilation rate, chlorophyll fluorescence and photochemical reflectance index in relation to leaf temperature. Plant Prod. Sci. 8: 131-138.

Li D, Liu H, Qiao Y, Wang Y, Cai Z, Dong B, Shi Ch, Liu Y, Li X and Liu M, 2013. Effects of elevated $\mathrm{CO}_{2}$ on the growth, seed yield, and water use efficiency of soybean (Glycine $\max$ (L.) Merr.) under drought stress. Agric. Water Manage. 129: $105-112$.

Liu F, Jensen ChR and Andersen MN, 2004. Drought stress effect on carbohydrate concentration in soybean leaves and pods during early reproductive development: its implication in altering pod set. Field Crop Res. 86: 1-13.

Liu X, Jin J, Herbert SJ, Zhang Q and Wang G, 2005. Yield components, dry matter, LAI and LAD of soybeans in Northeast China. Field Crop Res. 93: 85-93

Maleki A, Naderi A, Naseri R, Fathi A, Bahamin S and Maleki R, 2013. Physiological Performance of Soybean Cultivars under Drought Stress. Bull. Environ. Pharmacol. Life Sci. 2(6): 38-44.

Manavalan LP, Guttikonda SK, Tran LSP and Nguyen HT, 2009. Physiological and molecular approaches to improve drought resistance in soybean. Plant Cell Physiol. 50: 1260-1276.

Medic J, Atkinson C and Hurburgh Jr ChR, 2014. Current Knowledge in Soybean Composition. J. Am. Oil Chem. Soc. 91: 363-384.

Mutava RN, Prince SJK, Syed NH, Song L, Valliyodan B, Chen W and Nguyen HT, 2015. Understanding abiotic stress tolerance mechanisms in soybean: A comparative evaluation of soybean response to drought and flooding stress. Plant Physiol. Biochem. 86: 109-120.

Pagter M, Bragato C and Brix H, 2005. Tolerance and physiological responses of Phragmites australis to water deficit. Aquat. Bot. 81: 285-299.
Purcell LC and King CA, 1996. Drought and Nitrogen Source Effects on Nitrogen Nutrition, Seed Growth and Yield in Soybean. J. Plant Nutr. 19: 969-993.

Rahdari P and Hoseini SM, 2012. Drought stress, a review. Int. J. Agron. Plant Prod. 3: 443-446.

Rotundo JL and Westgate ME, 2009. Meta-analysis of environmental effects on soybean seed composition. Field Crop Res. 110: 147-156.

Sadeghipour O and Abbasi S, 2012. Soybean Response to Drought and Seed Inoculation. World App. Sci. J. 17(1): 55-60.

Samarah NH, Mullen RE, Cianzio SR and Scott P, 2006. Dehydrin-like proteins in soybean seeds in response to drought stress during seed filling. Crop Sci. 46: 2141-2150.

Sincik M, Candogan BN, Demirtas C, Büyükacangaz H, Yazgan S and Gksoy AT, 2008. Deficit irrigation of soybean [Glycine $\max$ (L.) Merr.] in a sub-humid climate. J. Agron. Crop Sci. 194: 200-205.

Sinclair T and Serraj R, 1995. Legume Nitrogen-Fixation and Drought. Nature. 378: 344.

Smiciklas KD, Mullen RE, Carlson RE and Knapp AD, 1992. Soybean seed quality response to drought stress and pod position. Agron. J. 84: 166-170.

Suzuki R, Tanaka S and Yasunari T, 2000. Relationships between Meridional Profiles of Satellite-derived Vegetation Index (NDVI) and Climate over Siberia. Int. J. Climatol. 20: 955-967.

Vurukonda SSKP, Vardharajula S, Shrivastava M and SkZ A, 2016. Enhancement of drought stress tolerance in crops by plant growth promoting rhizobacteria Microbiol. Res. 184: 13-24.

Wang J, Price KP and Rich PM, 2001. Spatial Patterns of NDVI in Response to Precipitation and Temperature in the Central Great Plains. Int. J. Remote Sens. 22: 3827-3844.

Wang Y and Frei M, 2011. Stressed food - The impact of abiotic environmental stresses on crop quality. Agric. Ecosyst. Environ. 141: 271-2

\section{Contribution of Authors}

Basal O: Conceived idea, designed research methodology, collected \& analysed data and article write up

Szabó A: Helped in data collection, analysis and article write up 